\title{
ABNORMALITIES IN THE GABAergic INHIBITORY SYSTEM LEADING TO THE DEVELOPMENT OF SPIKE-WAVE DISCHARGES IN THE SOMATOSENSORY CORTEX OF WAG/Rij RATS
}

\author{
Received April 23, 2014
}

We investigated the effects of muscimol on generation of spike-wave discharges (SWDs) and short-term plasticity alterations in the somatosensory cortex of WAG/Rij rats. The rats were implanted with a twisted tripolar electrode into the above cortex region and with an intraventricular cannula into the right cerebral ventricle. EEG recordings were made before and after muscimol and saline injections. Paired-pulse stimulations $(200 \mu \mathrm{sec}, 100-1000$ $\mu \mathrm{A}, 0.1 \mathrm{sec}^{-1}$ ) were applied to the somatosensory cortex at 50-, 100-, 400-, and 500-mseclong intervals for $50 \mathrm{~min}$. Pharmacological amplification of GABAergic transmission in the somatosensory cortex exerted an inhibitory effect on the thalamo-cortical circuit underlying the generation of spike-wave discharges (SWDs). Ten minutes post-injection of muscimol, paired-pulse facilitation was significantly reduced at 50- and 100-msec-long interpulse intervals $(P<0.05)$. The data obtained suggest that muscimol suppresses generation of SWDs and changes short-term plasticity via imitation of the effects of GABA in inhibitory synapses.

Keywords: absence epilepsy, WAG $\backslash$ Rij rats, somatosensory cortex, GABAergic system, muscimol, paired-pulse stimulation.

\section{INTRODUCTION}

Absence epilepsy is manifested in a transient loss of consciousness, while the episodes of seizures are not stable [1]. Other protests are related to a motionless state and arrest of ongoing mental and motor activity, changes in the heart rate, pupil reactions, sweating, and initiation of clonico-tonic seizures [2]. Electrographic manifestations (waves of absence seizures) appear bilaterally and simultaneously in both brain hemispheres. As is believed, the main cause of this type of epilepsy is the dysfunction of thalamocortical circuits, but there are many other ideas on triggering mechanisms of this network disorder.

We examined the function of $\mathrm{GABA}_{\mathrm{A}}$ receptors using WAG/Rij rats, which are a reliable genetic model for human absence epilepsy. In these animals, spike-wave discharges (SWDs) are generated and circulate in the cortico-thalamo-cortical network [3].

\footnotetext{
1,2 Tabriz University of Medical Sciences, Tabriz, Iran ('Neurosciences Research Center; ${ }^{2}$ Drug Applied Research Center).

${ }^{3}$ Department of Physiology, National Medical University, Odessa, Ukraine.

${ }^{4}$ Department of Physiology, Faculty of Medicine, Urmia University of Medical Sciences, Urmia, Iran.

Correspondence should be addressed to G. G. Nejad

(e-mail: Gh_ghamkhar@yahoo.com),or

P. Shahabi (e-mail: parvizshahabi@gmail.com).
}

A hot-spot region where SWDs are produced has been identified in the somatosensory perioral area [4]. A phenomenon of local hyperexcitability of the somatosensory cortex (SSC) is in agreement with the cortical focus theory for generation of absence seizures; further evidence supported that a balance between the excitatory and inhibitory systems is impaired in WAG/ $\mathrm{Rij}$ rats [5]. GABA is a key player in adjusting this balance [6]. By activation of $\mathrm{GABA}_{\mathrm{A}}$ inotropic receptors, chloride ions enter the cells and prevent the development of new action potentials (APs) through hyperpolarization of the cell membrane; shunting of the membrane also plays a role. These receptors often exist in synaptic terminals and are responsible for presynaptic inhibition based in suppression of the release of neurotransmitters [7].

Most mutations causing epilepsy are related to the genes of voltage- or ligand-gated channels [8]. For example, genetic evidence has shown that mutations related to $\alpha_{1}, \gamma_{2}$, and $\delta$ subunits are associated with symptoms of epilepsy in the cortex [9]. Reduced expression of these subunits results in a decrease in tonic GABA currents due to certain different rearrangings of $\mathrm{GABA}_{\mathrm{A}}$ receptors. It seems that gatherings of various forms of $\mathrm{GABA}_{\mathrm{A}}$ receptor subunits play a key role in the determination of 
characteristics of phasic and tonic GABAergic currents. The receptors including $\alpha_{4} / \delta$ subunits are characterized by specific performance features leading to initiation of seizure activity in the cortex, especially in the temporal lobes [10].

Short-term synaptic plasticity (STP) is an important factor influencing the synaptic communication within the brain. Typically, it is assessed with pairedpulse stimulation allowing one to demonstrate the phenomena of paired-pulse facilitation (PPF) and paired-pulse depression (PPD) $[11,12]$. Investigation of cellular mechanisms of cortical STP helps to discover the contention of GABA receptors [13]. However, there is practically no information on the involvement of $\mathrm{GABA}_{\mathrm{A}}$ receptors in $\mathrm{STP}$ in absence epilepsy.

Taking into account the facts and considerations mentioned above, we hypothesized that modification of the GABAergic inhibitory system in the SSC1 (S1) cortical zone is probably responsible for generation of SWDs. Administration of muscimol was used in our study to reveal possible effects of amplification of synaptic inhibition and subsequent changes in SWDs and short-term plasticity in the above animal model of absence epilepsy.

\section{METHODS}

Animal Groups. In vivo experiments were carried out on 18 adult male WAG/Rij rats (6-10 months old, weighing 250-300 g) randomly divided into three groups, six rats in each (control, saline, and muscimol, C, S, and M). Animals were obtained from a maintained colony in the Shefa Neuroscience Center (Khatam Hospital, Tehran, Iran) and kept under controlled environmental conditions (temperature $23 \pm 1{ }^{\circ} \mathrm{C}$, humidity $40 \%, 12 / 12 \mathrm{~h} \mathrm{light/dark} \mathrm{cycle,} \mathrm{and}$ free access to food and water).

Surgical Procedure. Animals were anesthetized by i.p. injections of ketamine (ketamine hydrochloride, Sigma-Aldrich Chemie, Germany; $60 \mathrm{mg} / \mathrm{kg}$ ) and xylazine (RXV, USA; $12 \mathrm{mg} / \mathrm{kg}$ ) [14]. A twisted tripolar electrode was prepared from Teflon-coated stainless steel wire (diameter $100 \mu \mathrm{m}$ ); this set of two stimulating electrodes and one recording electrode was implanted into the somatosensory perioral (S1po) and primary somatosensory forelimb $(\mathrm{S} 1 \mathrm{fl})$ cortical zones (AP -2.1, $\mathrm{L} \pm 0.5, \mathrm{~V} 4.0 \mathrm{~mm}$ and $\mathrm{AP}-2.1$, $\mathrm{L} \pm 3.0, \mathrm{~V} 2.0 \mathrm{~mm}$ relative to the bregma, respectively) using a stereotaxic device (Stoelting, USA). A reference electrode was located on the occipital cortex. Electrodes were fixed in the sockets by pins. A 23 -gauge cannula for drug injection was implanted into the right lateral cerebral ventricle (AP $-0.8, \mathrm{~L} \mathrm{1.6}$, and $\mathrm{V} 3.5 \mathrm{~mm}$ below the dura) in all rats according to the atlas [15]. A short cooper wire stilet was interpolated inside the cannula in order to avoid its shutting. The cannula and sockets were fixed to the skull by dental cement. Before injection, the stilet was removed and replaced with an injection needle (27-gauge) connected to a 10- $\mu$ l Hamilton syringe. Muscimol (MW114.10, Sigma, USA) was dissolved in $0.9 \%$ saline for direct microinjection. Five microliters of pure saline or solution containing $1 \mu \mathrm{g} / \mathrm{kg}$ muscimol were injected into the right lateral ventricle [16].

Stimulation and Recording. After a 1-weeklong recovery period, the experiments were carried out. Rats were put into a Faraday cage, and ECoG was recorded after a 30 -min-long adaptation to the experimental conditions in a freely moving behavior mode. Spike-wave discharges were recorded $60 \mathrm{~min}$ before and three times after drug injections (with 30 -min-long intervals). Square pulses $(200 \mu \mathrm{sec}$, 100-1000 $\left.\mu \mathrm{A}, 0.1 \mathrm{sec}^{-1}\right)$ were applied to the somatosensory cortex. Each experiment began by determining the stimulus intensity dependence to elicit the threshold and maximal evoked potentials (EPs). After the EP threshold was determined, the excitation intensity was raised to the value eliciting 50\%-maximum EPs, and this was used as the test stimulus during the experiment. The EPs were amplified and filtered ( 0.1 to $1 \mathrm{kHz}$ bandpass $)$ using a differential amplifier (DAM80, WPI, USA). Signals were passed through an AD (USB-6221-BNC, National Instruments, USA) to a computer. Data were digitized at a sampling rate of $10^{3} \mathrm{sec}^{-1}$ and analyzed by the means of Win LTP software (version 2.01, M-Series, University of Bristol, Great Britain). The EP amplitude was measured as the voltage difference between the baseline and peak of the EP wave. Later, paired-pulse stimulation was applied to the SSC with interstimulus intervals of $50,100,400$, or $500 \mathrm{msec}$ between the conditioning (first) and test (second) stimulations. Five responses were sampled and averaged for each interval. All paired pulses were delivered at a $0.1 \mathrm{sec}^{-1}$ frequency.

Histology. At the end of experiments, the rats were deeply anesthetized with a high dose of ketamine; the brain was removed quickly and fixed in $10 \%$ formalin solution for $24 \mathrm{~h}$ at room temperature. Subsequently, $40 \mu \mathrm{m}$-thick coronal slices were cut by a vibroslicer 
(Campden-MA752, Great Britain). Positions of the electrode tips and cannula were pointed by cresyl Violet staining. Two animals were excluded from the analysis because the electrodes and cannula had not been placed appropriately.

Statistical Analysis. SPSS 16 was used for statistical analysis. The SWD parameters were analyzed by one-way and repeated-measures ANOVA. The Tukey's test was administered for posthoc analysis. Baseline data were taken as $100 \%$, and values were expressed as percentages with respect to the baseline ones. In order to compare the effects of paired-pulse stimulation related to the zone and time interval, mixed models with an autoregressive (1) covariance structure and with a restricted maximum likelihood (REML) in the form of the estimation method were used. The analyses were followed by the Sidok post-hoc test. Differences with $P<0.05$ were considered statistically significant.

\section{RESULTS}

Effects of Muscimol on SWDs. To compare the effects of muscimol and saline (control) microinjections on SWDs, the mean number and mean duration of these events were investigated within three 30 minlong intervals following drug or saline injections. Checking parameters in the $\mathrm{S}$ group (saline) showed that the mean duration and frequency of SWDs within the first, second, and third interval after injection of saline showed no significant differences from the baseline values $(P>0.05)$. At the same time, the

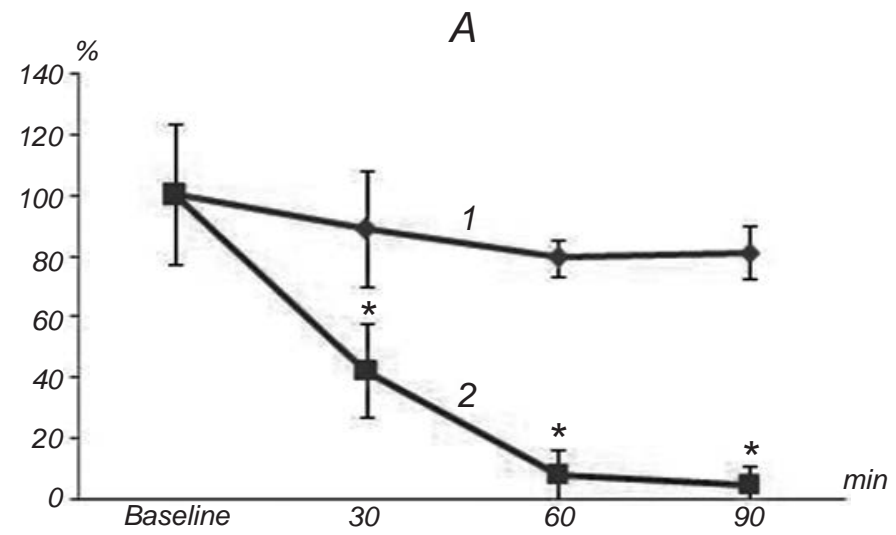

mean duration of SWDs within all three intervals after musicmol injection (group $M$ ) showed significant decreases compared to the control $(P<0.05)$. The mean values were: $45.0 \pm 11.7 \%$ in the first, $32.1 \pm 12.0 \%$ in the second and $30.4 \pm 7.4 \%$ in the third 30-min interval relative to the control (Fig. 1B).

In muscimol-injected animals, significant decreases were also observed in the number of SWDs compared with the control within all the three post-injection periods $(P<0.05)$. The percentages were $42.3 \pm 11.7 \%$, $10.0 \pm 8.4 \%$, and $5.1 \pm 1.5 \%$, respectively (Fig. $1 \mathrm{~A}$ ).

Effects of Muscimol on the Effects of Paired-Pulse Stimulation. Evoked potentials were elicited in the S1po and S1fl by means of paired-pulse stimulation, and the paired-pulse ratio (PPR) was calculated at different interpulse intervals. Paired- pulse facilitation (PPF) was clearly seen at all (50-, 100-, 400-, and 500-msec-long) intervals under basic conditions. According to the results of muscimol injection, a significant decrease in the above effect and manifestation of PPD were seen at 50- and 100-mseclong intervals $(P<0.05)$. No significant difference was observed between the effects at these intervals during the second to fifth 10 -min post-injection periods $(P>0.05)$. Declines toward PPD were most clearly observed at $100-\mathrm{msec}$ interpulse intervals. At the intervals of 400 and $500 \mathrm{msec}$, significant reductions of PPF were not observed in comparison to the baseline records. In this study, the zone effect was insignificant; the values of the PPR in the S1fl were nearly similar to those acquired from the S1po $(P>$ 0.05) (Fig. 2).

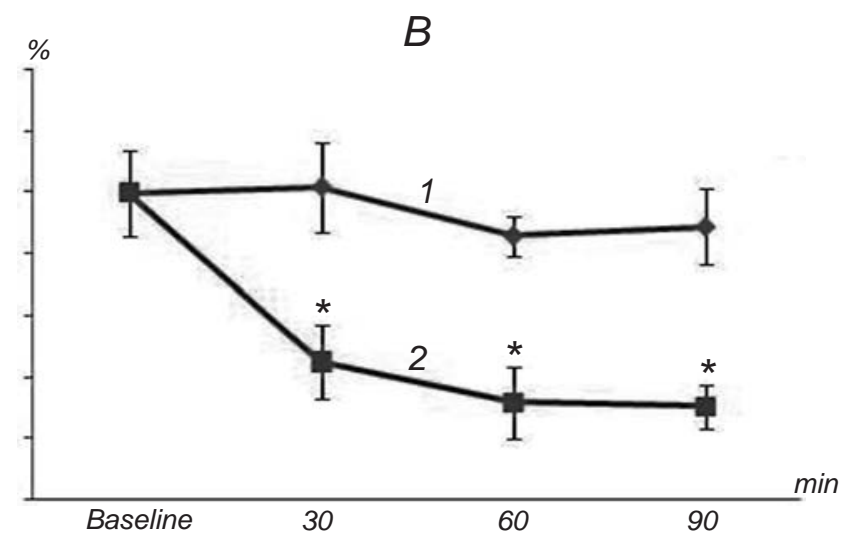

F i g. 1. Dynamics of the effects of muscimol on the mean normalized number (A) and duration (B) of spike-wave discharges within three consequent 30 -min-long post-injection intervals. Baseline indices are taken as $100 \% .1$ is the control (saline); 2 is muscimol. Data were analyzed by the one-way ANOVA test. Asterisks show cases of significant differences from the baseline values $(P<0.05)(n=6$ for each group).

Р и с. 1. Динаміка впливів мусцимолу на нормовані середні значення кількості $(A)$ та тривалості $(B)$ комплексів пік-хвиля. 

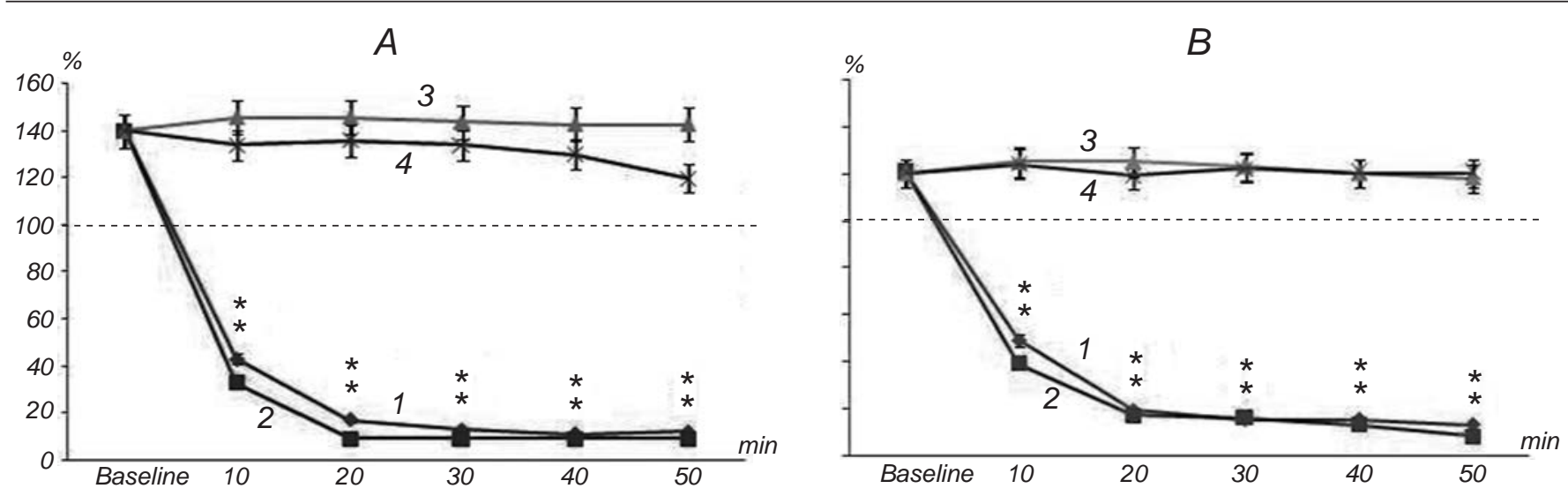

F i g. 2. The time course of the effects of muscimol on the pair-pulse ratio (PPR, \%) in the S1 po (A) and S1fl (B) cortical regions. Values were analyzed by the mixed model test with autoregressive covariance structure. Values are shown as the percentage of the mean EEP2/EEP1 at IPIs 50, 100, 400, and $500 \mathrm{msec}$ within five subsequent 10 min-long post-injection intervals. *Significant difference from the baseline values $(P<0.05 ; n=6$ in each group).

P и с. 2. Часовий перебіг впливів мусцимолу на відношення другого та першого ефектів при парній стимуляції (PPR) у кортикальних зонах $\mathrm{S} 1$ ро $(A)$ та S1fl $(B)$.

\section{DISCUSSION}

The purpose of our study was to determine the efficacy of GABAergic inhibitory amplification on SWD generation and conversion in short-term synaptic plasticity in the somatosensory cortex of epileptic rats. To this aim, muscimol, a well-known $\mathrm{GABA}_{\mathrm{A}}$ receptor agonist, was used. Our results after intracerebral microinjections of muscimol demonstrated reductions in the mean duration and number of SWDs. Also, under conditions of paired-pulse stimulation of the SSC, the above-mentioned facilitation diminished significantly.

The activity of the GABAergic inhibitory system is decreased significantly in the frontal and parietal cortex of WAG/Rij rats. Mutation of the $\mathrm{GABA}_{\mathrm{A}}$ receptor-coding gene, inadequate synthesis of the neurotransmitter (GABA), and GABA receptor internalization can lead to the development of absence epilepsy [4]. Some pathophysiological changes, such as alteration of normal GABA receptor-mediated tonic inhibition and $\mathrm{GABA}_{\mathrm{A}}$ receptor internalization in the respective synapses, lead to significant imbalance in the cortical neuronal networks [17].

In line with our results, there is a demonstration that bilateral injections of muscimol into the substantia nigra significantly reduced SWDs in EEGs, and such injections can inhibit seizures induced by pentilenetetrazole (PTZ) applications [18]. Another study on the thalamic nuclei stated that muscimol injections into these structures suppressed tonic and clonic seizures associated with consciousness impairment [19]. Today, it has been proven that the inhibitory action of GABA is not only determined by the parameters of phasic postsynaptic inhibition (classic IPSPs), but also by interaction with presynaptic GABA receptors, which influences tonic inhibition. In vitro studies on the thalamic nuclei in different models of absence epilepsy proved that tonic currents in these models have been significantly reduced compared to those in control animals [6].

Diminution of tonic inhibitory currents are due to a large number of GABA neurotransmitter transporters (GAT1) in presynaptic terminals of inhibitory interneurons. These transporters are rather numerous in the thalamic nuclei and SSC. In the regions, in which these transporters are not available, GABA is not reuptaken and remain in synapses; therefore, a greater GABA amount arrives in the synaptic space, more GABA binds to $\mathrm{GABA}_{\mathrm{A}}$ receptors, and this leads to induction of stronger tonic GABA currents [20].

Changes in PPF are often used as an indicator of short-term plasticity characteristics. To evaluate the effect of the GABA agonist on short-term synaptic plasticity, we used a paired-pulse stimulation pattern, which is a suitable method to study the excitability of cortico-thalamic networks. By muscimol injections into the brain ventricle and paired-pulse stimulation with different intervals, short-term synaptic plasticity changes have been clearly seen. At short IPIs (50 and $100 \mathrm{msec}$ ), PPF manifested under basic conditions is changed to PPD. In the $M$ group, this result is in line with those showing increased responses of $\mathrm{GABA}_{\mathrm{A}}$ receptors at induction of PPD in the superior colliculus, hippocampus, and neocortex [21]. 
The results obtained allow us to conclude that muscimol leads to suppression of SWDs by imitating inhibitory effects of excessive GABA amounts present in the synaptic space. With more follow-up research, such as investigation of the inhibitory circuits by paired-pulse stimulation, it can be found that the efficacy of muscimol with respect to inhibitory interneurons affects short-term plasticity. Muscimol increases inhibitory currents at inhibitory terminals and leads to a considerable reduction of PPF under conditions of paired-pulse stimulation.

Acknowledgments. This research was financially supported by the Neuroscience Research Center of the Tabriz University of Medical Sciences (Tabriz, Iran).

The experiments were carried in accordance with the existing international ethical norms and approved by the Regional Ethics Committee of the Tabriz University of Medical Sciences (Tehran, Iran).

The authors, G. G. Nejad, R. S. Vastyanov, P. Shahabi, M. R. Alipoor, and F. G. Pakdel, confirm that they have no conflict of interest with any organization or person that may be related to this study; there were also no conflict of interest in interrelations between the authors.

\section{Г. Г. Неджад ${ }^{1}$, Р. С. Васт'янов ${ }^{2}$ П. Шахабі ${ }^{1}$, М. Р. Аліпур ${ }^{3}$, Ф. Г. Пакдель ${ }^{4}$}

\section{ВПЛИВИ МОДУЛЯЦІЇ ГАМК-ЕРГІЧНОЇ ГАЛЬМІВНОЇ СИСТЕМИ НА РОЗВИТОК КОМПЛЕКСІВ ПІК-ХВИЛЯ В СОМАТОСЕНСОРНІЙ КОРІ ЩУРІВ ЛІНІЇ WAG/Rij}

${ }^{1}$ Центр досліджень у сфері нейронаук Табризького медичного університету (Іран).

\footnotetext{
2 Дослідницький центр прикладної фармакології Табризького медичного університету (Іран).

${ }^{3}$ Одеський національний медичний університет (Україна).

${ }^{4}$ Медичний університет у м. Урмія (Іран).

P е 3 ю м е
}

Ми досліджували впливи мусцимолу на генерацію комплексів пік-хвиля (КПХ) та феномен короткочасної пластичності у щурів лінії WAG/Rij. Тваринам імплантували триполярний електрод у соматосенсорну кору та канюлю в правий мозковий шлуночок. Перед внутрішньошлунковою ін'єкцією мусцимолу або фізіологічного розчину реєстрували ЕЕГ. Соматосенсорну кору стимулювали парними стимулами (200 мкс, 100-1000 мкА, $0.1 \mathrm{c}^{-1}$ ) 3 інтервалами 50, 100,400 або 500 мс протягом 50 хв. Фармакологічне посилення ГАМК-ергічної передачі в соматосенсорній корі призводило до гальмування таламо-кортикальних нейромереж, відповідальних за генерацію КПХ. Через 10 хв після ін'єкції мусцимолу полегшення при парній стимуляції істотно зменшувалось та переходило у депресію у тих випадках, коли міжстимульні інтервали дорівнювали 50 або 100 мс $(P<0.05)$. Як вказують отримані дані, мусцимол пригнічує генерацію КПХ та змінює короткочасну пластичність, оскільки він імітує дію ГАМК у гальмівних синапсах.

\section{REFERENCES}

1. O. C. Snead, "Basic mechanisms of generalized absence seizures," Ann. Neurol., 37, No. 2, 146-157 (1995).

2. G. D'Arcangelo, M. D'Antuono, G. Biagini, et al., "Thalamocortical oscillations in a genetic model of absence seizures," Eur. J. Neurosci., 16, No. 12, 2383-2393 (2002).

3. E. van Luijtelaar and A. Coenen, "Two types of electrocortical paroxysms in an inbred strain of rats," Neurosci. Lett., 70, No. 3, 393-397 (1986)

4. G. van Luijtelaar and E. Sitnikova, "Global and focal aspects of absence epilepsy: the contribution of genetic models," Neurosci. Biobehav. Rev., 30, No. 7, 983-1003 (2006).

5. A. Lüttjohann, S. Zhang, R. de Peijper, and G. van Luijtelaar, "Electrical stimulation of the epileptic focus in absence epileptic WAG/Rij rats: assessment of local and network excitability," Neuroscience, 188, 125-134 (2011).

6. A. M. L. Coenen and E. van Luijtelaar, "The WAG/Rij rat model for absence epilepsy: age and sex factors," Epilepsy Res., 1, No. 5, 297-301 (1987).

7. L. Parsaei, M. Rangchiyan, S. Ahmadi, and M. R. Zarrindast, "GABAA receptors in the dorsal hippocampus are involved in sate-dependent learning induced by lithium in mice," Iran J. Pharm. Res., 10, No. 1, 127 (2011).

8. M. Tian and R. L. Macdonald, "The intronic GABRG2 mutation, IVS6 $+2 \mathrm{~T} \rightarrow \mathrm{G}$, associated with childhood absence epilepsy altered subunit mRNA intron splicing, activated nonsense-mediated decay, and produced a stable truncated $\gamma 2$ subunit," J. Neurosci., 32, No. 17, 5937-5952 (2012).

9. C. A. Reid and D. M. Kullmann, "GABA A receptor mutations in epilepsy (Commentary on Lachance, Touchette, et a1.)," Eur. J. Neurosci., 34, No. 2, 235, (2011).

10. H. P. Goodkin, C. Sun, J. L. Yeh, et al., "GABA A receptor internalization during seizures," Epilepsia, 48, s5, 109-113 (2007).

11. D. Debanne, N. C. Guerineau, B. Gähwiler, and S. M. Thompson, "Paired-pulse facilitation and depression at unitary synapses in rat hippocampus: quantal fluctuation affects subsequent release," J. Physiol., 491, No. 1, 163-176 (1996).

12. C. F. Stevens and Y. Wang, "Facilitation and depression at single central synapses," Neuron, 14, No. 4, 795-802 (1995).

13. M. A. Castro-Alamancos and B. W. Connors, "Cellular mechanisms of the augmenting response: short-term plasticity in a thalamocortical pathway," J. Neurosci., 16, No. 23, 7742-7756 (1996).

14. Z. Ataie, S. Babri, M. G. Golzar, et al., "GABA B receptor blockade prevents antiepileptic action of ghrelin in the rat hippocampus," Adv. Pharm. Bull., 3, No. 2, 353 (2013).

15. G. Paxinos and C. Watson, The Rat Brain in Stereotaxic Coordinates: Hard Cover Edition, Acad. Press (2006). 
16. T. Baum and F. Becker, "Hypotensive and postural effects of the [gamma]-aminobutyric acid agonist muscimol and of clonidine," J. Cardiovascul. Pharmacol., 4, No. 2, 165-159 (1982).

17. Y. Ma and D. A. Prince, "Functional alterations in GABAergic fast-spiking interneurons in chronically injured epileptogenic neocortex," Neurobiol. Dis., 47, No. 1, 102-113 (2012).

18. A. Depaulis, M. Vergnes, C. Marescaux, et al., "Evidence that activation of GABA receptors in the substantia nigra suppresses spontaneous spike-and-wave discharges in the rat," Brain Res., 448, No. 1, 20-29 (1988).
19. J. C. Mulley, I. E. Scheffer, S. Petrou, and S. F. Berkovic, "Channelopathies as a genetic cause of epilepsy," Current Opin. Neurol., 16, No. 2, 171-176 (2003).

20. H. K. Meeren, J. G. Veening, T. A. Möderscheim, et al., "Thalamic lesions in a genetic rat model of absence epilepsy: dissociation between spike-wave discharges and sleep spindles," Exp. Neurol., 217, No. 1, 25-37 (2009).

21. D. Merlo, C. Mollinari, Y. Inaba, et al., "Reduced GABA B receptor subunit expression and paired-pulse depression in a genetic model of absence seizures," Neurobiol. Dis., 25, No. 3, 631-641 (2007). 